\title{
RELEVANCE OF THE PROBLEM OF PREPARING TEACHING AID IN CHINESE FOR CHILDREN OF PRESCHOOL AGE
}

\author{
Karima Shavkat Kizi Akhmadova \\ Student, Department Of Chinese Philology Tashkent State University Of Oriental Studies, Uzbekistan
}

\section{ABSTRACT}

The article discusses the importance of teaching a foreign language to children of preschool age, and also analyzes a study on this issue. Particular attention is paid to the relevance and importance of the introduction of the Chinese language into the educational process in preschool institutions, the idea of creating a textbook in Chinese for Uzbek-speaking groups is put forward.

KEYWORDS: - Sensitive period, psychology, speech mechanism, communication, foreign language, preschool age, interstate partnership..

\section{INTRODUCTION}

Currently, the issue of early development and teaching children a foreign language is relevant and is determined by the requirements of modern world development. In this context, the President of the Republic of Uzbekistan ShavkatMirziyoyev in his message to the Oliy Majlis noted the study of foreign languages as a priority ${ }^{1}$. In this regard, in Uzbekistan, special attention is paid to teaching foreign languages to preschool children. Foreign languages such as English, Chinese are being introduced in preschool educational institutions, there are also private preschool educational institutions with a focus on French and German.

More and more parents seek to introduce their children to foreign languages from an early age.

${ }^{1}$ Message from the President of the Republic of Uzbekistan ShavkatMirziyoyev to the Oliy Majlis. -2020.
Early education allows you to reveal the language abilities of children, develop all types of thinking and memory, creativity and imagination, arouses interest in languages, cultures of other nations, contributes to the development of communicative-speech tact. The problem of early learning is the need to look for reserves in the organization of education in order to take advantage of the sensitive period of mastering foreign languages in preschool age. Experimental studies indicate that after the child reaches the age of nine, the flexibility of the speech mechanism is partially lost, while the age of five is optimal for starting learning a foreign language.

Cooperation between Uzbekistan and China,

\footnotetext{
${ }^{2}$ Sensitive periods are called periods of special susceptibility of children to certain methods, types of activity; to the ways of emotional reaction, behavior in general, etc. - to the extent that each character trait develops most intensively on the basis of some inner impulse and over a certain narrow period of time.
} 
CURRENT RESEARCH JOURNAL OF PHILOLOGICAL SCIENCES 2(7): 13-15,

May 2021 DOI: https://doi.org/10.37547/philological-crjps-02-07-04

ISSN 2767-3758

(C)2021 Master Journals

\section{Crossref do) 8 Google}

Accepted23thJuly, 2021 \& Published 28 thJuly, 2021

based on the principles of friendship, mutual respect and trust, as well as having the character of a strategic partnership, is becoming closer every year and is filled with new practical content. Especially interstate, friendly relations are clearly manifested in the field of preschool education. A striking example is the meeting of the Minister of Preschool Education of the Republic of Uzbekistan Angrippina Shin with the Ambassador Extraordinary and Plenipotentiary of the People's Republic of China to the Republic of Uzbekistan Jiang Yan in the city of Tashkent in 2020. Topical issues of current and future cooperation were discussed at the meeting. In particular, they discussed the issues of attracting investments for organizing the production of developmental toys, play equipment, as well as didactic materials in the territory of the Republic of Uzbekistan, expanding networks of non-state preschool educational organizations on the basis of public-private partnerships.The possibility of studying the Chinese language, as one of the foreign ones, in state preschool educational institutions and the need to organize refresher courses for specialists of the preschool education system were also considered. ${ }^{3}$

The introduction of the Chinese language into preschool educational organizations is a pressing issue, but at the same time, a complex process. Since in the course of research it turned out that in the Republic until now, teaching materials for teaching the Chinese language have not been developed. However, the demand for these materials is very high: since in many preschool educational institutions of the capital, including in private kindergartens, children are taught the Chinese language at specialized school No. 59 in the city of Tashkent. It was found that many

\footnotetext{
${ }^{3}$ Bozhovich L.I. Problems of the development of the child's motivational sphere // Study of the motivation of behavior in children and adolescents / ed. L.I. Bozhovich, L.V. Trustworthy - M .: Pedagogika, 1972 .- p. 7-44.
}

teachers in these institutions face the problem of a shortage of teaching aids in the Chinese language. Having studied the existing teaching language materials on the Chinese language for preschool children, the idea of creating a textbook for children 6-7 years old was put forward.

When studying teaching aids on the Chinese language for preschool education, it was found that most textbooks are in Russian and English, moreover, they are adapted for teaching primary school students. In this regard, it was proposed to create a textbook in the Uzbek language for the Uzbek-speaking groups with the age category of 6-7 years.

It should be noted that today in the capital of the Republic there are a number of private preschool institutions in which the teaching of the Chinese language has already been introduced. During the study of these institutions, it was found that children quickly and easily learn Chinese, despite the complexity of the language. Since young children have their own characteristics, on the one hand, they are not afraid to speak and make mistakes, which allows them to quickly master speaking skills. A child can easily learn Chinese, like any other foreign language at an early age, according to the principle of bilingualism. On the other hand, a playful approach to learning is important for children. The conclusion of the research is confirmed that early teaching of foreign languages should be built, first of all, on play activities, which are aimed at the development and upbringing of the child. Since the leading activity at this age is the game form: the use of music and singing in the classroom of the Chinese language contributes to a more effective mastery of students' language, speech, socio-cultural knowledge, skills and abilities, contributing to the formation of communicative competence, that is, the ability and readiness to use a foreign language in the process of intercultural interaction in typical situations of 
CURRENT RESEARCH JOURNAL OF PHILOLOGICAL SCIENCES 2(7): 13-15,

May 2021 DOI: https://doi.org/10.37547/philological-crjps-02-07-04

ISSN 2767-3758

(C)2021 Master Journals

\section{Crossref do) 8 Google}

Accepted23 ${ }^{\text {th } J u l y, ~} 2021$ \& Published 28thJuly, 2021

oral and written communication. The manual we offer is aimed at developing the communicative, speech and intellectual abilities of preschool children. For example, this study guide consists of activities and activities to help your child think and work in a group. For the development of auditory and speech skills, songs and rhymes are given in each lesson, so that it is interesting for children to attach multimedia videos, with which it will be even easier for them to learn songs. Another feature of our manual is that we have included interesting facts and information about the culture of China, thus, when learning this language, children will form an idea of the culture and customs of this country.

In conclusion, it should be noted that at the moment the issue of the early start of teaching children the Chinese language is a relevant and important defining requirement of modern society. A theoretical analysis of psychological and pedagogical literature has shown that preschool age is the most favorable for starting the study of the Chinese language. Children 4-6 years old are distinguished by the natural motives of communication, the absence of a language barrier, fear of inhibition, preschoolers more flexibly and quickly memorize language material. Our proposed textbook for teaching the Chinese language to children of 6-7 years old will contribute to the development of communicative, speech and intellectual abilities in children, and will also serve as a basic material for acquaintance with Chinese culture.

\section{REFERENCE}

1. Message from the President of the Republic of Uzbekistan ShavkatMirziyoyev to the Oliy Majlis. -2020.

2. Bozhovich L.I. Problems of the development of the child's motivational sphere // Study of the motivation of behavior in children and adolescents / ed. L.I. Bozhovich, L.V. Trustworthy - M .: Pedagogika, 1972 .- p. 744.

3. Leontiev, A.N. Psychological foundations of child development and education / A.N. Leontiev; ed. A.A. Leontiev, D.A. Leontyev. M .: Smysl 2009.509-519 p.

4. Lomakina, G.R. Early teaching of a foreign language: pros and cons / G.R. Lomakina, A.A. Laer // Young Scientist. - 2014. - No. 20. - S. 597-599.

5. Azarov Yu. P. Family pedagogy. Series "Master of Psychology". - SPb: Publishing house "Peter", 2011. - 400 p.

6. Pestalozzi I. G. Selected pedagogical works: in 2 volumes. Vol. 2. - M.: Pedagogika, 1981.- 416 p.

7. Rousseau J.-J. Pedagogical works in 2 volumes. Volume 1. Emil, or About education. - M.: Pedagogika, 1981.- 656 p.

8. Shchukin A.N. Teaching foreign languages: Theory and practice: a textbook for teachers and students. M.: Filomatis, 2006.480 p.

9. Zotova O.A., Andrianova T.N., Ivanova S.R.Features of teaching a foreign language at preschool age // Proceedings of the Intern. scientific-practical conf. "The German language in the era of globalization: challenges and prospects" (Ulyanovsk, March 27-28, 2014g.) FGBOU VPO "UlGPUim. I.N. Ulyanov", 2014. P. 158-161.

10. Vanyushkina K. N., Grigorieva E. N. Modern approaches to teaching English to preschoolers // Questions of linguodidactics and intercultural communication in the context of modern research: collection of articles. scientific. tr. Cheboksary, 2019, p. 1519 